\title{
PERILAKU WISATAWAN PANTAI NGURBLOAT DAN NGURSARNADAN ERA NEW NORMAL TERHADAP KEPUTUSAN BERWISATA
}

\author{
Ida I Dewa Ayu Raka Susanty ${ }^{1}$, Melissa Justine Renjaan ${ }^{2}$ \\ Program Studi Agrowisata Bahari, Politeknik Perikanan Negeri Tual ${ }^{1,2}$, \\ ayususanty76@gmail.com ${ }^{1}$
}

\begin{abstract}
ABSTRAK
Wabah COVID-19 di seluruh dunia telah membuat dunia terhenti, dan pariwisata menjadi yang terpuruk dari semua sektor ekonomi utama di seluruh dunia tak terkecuali Indonesia. Pulau - pulau kecil di Indonesia timur yang menggantungkan perekonomian dari segi pariwisata bahari juga terkena dampak besar akibat situasi pandemi. Kabupaten Maluku Tenggara adalah salah satunya. Pelonggaran terhadap aktivitas industri pariwisata dimulai sejak diumumkannya masa new normal oleh pemerintah. Dua destinasi unggulan Kabupaten Maluku Tenggara yakni Pantai Ngurbloat dan Ngursarnadan memulai aktivitas pada kawasan wisata dengan jumlah pengunjung yang didominasi oleh wisatawan lokal. Tingginya wisatawan lokal yang berwisata, menunjukan kebutuhan masyarakat terhadap aktivitas berwisata sangat tinggi. Perilaku wisatawan terhadap keputusan berwisata dalam masa new normal dapat dipicu oleh berbagai faktor. Proses pengambilan keputusan wisatawan dalam berwisata ke destinasi wisata pantai Ngurbloat dan Ngursarnadan sangat penting diketahui oleh stakeholder atau pengelola kawasan wisata Tujuan dari penelitian ini adalah untuk mengetahui dan menjelaskan pengaruh perilaku wisatawan secara simultan terhadap keputusan berwisata, pengaruh secara parsial perilaku wisatawan terhadap keputusan berwisata serta faktor yang paling menonjol mempengaruhi keputusan wisatawan dalam berwisata pada Pantai Ngurbloat dan Ngursardanan. Metode pengumpulan data pada penelitian ini menggunakan kuesioner dan wawancara dengan analisa regeresi linier berganda. Hasil penelitian ini menunjukan bahwa faktor budaya, sosial, pribadi dan psikologis secara simultan berpengaruh terhadap keputusan wisatawan berkunjung ke pantai Ngurbloat dan Ngursarnadan. Sedangkan, pengaruh secara parsial hanya pada faktor sosial, pribadi dan psikologis berpengaruh terhadap keputusan wisatawan untuk berkunjung ke Pantai Ngurbloat dan Ngursarnadan. Faktor yang paling dominan mempengaruhi keputusan berwisata wisatawan adalah faktor psikologis dengan nilai Koefisien sebesar 0.497
\end{abstract}

Kata Kunci : Perilaku Wisatawan, Keputusan berwisata, Pantai Ngurbloat, Pantai Ngursarnadan

\begin{abstract}
The worldwide outbreak of COVID-19 has brought the world to a standstill, and tourism has been the worst affected of all major economic sectors in the entire world as well as Indonesia. In eastern Indonesia, the economy of small islands depends on the marine tourism sector which has been affected by the pandemic. Southeast Maluku Regency is one of the islands affected by pandemic. The government has suspended the activity of tourist and travel. The tourism industry is gradually starting to recovery and improve. reopened tourist areas in Southeast Maluku Regency have begun in August 2020 with the COVID-19 health protocol. Two leading destinations of Southeast Maluku Regency, Ngurbloat Beach and Ngursarnadan Beach, started activities in tourist areas with the
\end{abstract}

ISSN: 2355-6587, e-ISSN: 2528-2220

http://ejournal.bsi.ac.id/ejurnal/index.php/jp 
number of visitors dominated by local tourists. The purpose of this study was to know and explain the influence of tourist behavior simultaneously on travel decisions, the partial influence of tourist behavior on travel decisions and the dominant faktor influencing the decision of tourists in visiting Ngurbloat and Ngursardanan Beaches. The results of this study showed that cultural, social, personal and psychological faktors silmultan influence the decision of tourists visiting Ngurbloat and Ngursarnadan Beach. Meanwhile, the partial influence is only on social, personal and psychological factors on the decision of tourist to visit Ngurbloat and Ngursarnadan beach. The most dominant factor influencing the decision to travel is the psychological factor with a coefficient value of 0.497

Keywords: Tourist Behavior, Travel decisions, Ngurbloat Beach, Ngursarnadan Beach

\section{PENDAHULUAN}

Masa pandemi akibat wabah Novel Covorona Virus atau dikenal dengan nama lain covid-19 diseluruh dunia memberikan dampak besar bagi perekonomian dunia Penelitian lebih lanjut yang dilakukan oleh PBB menunjukan bahwa sedikitnya 120 juta pekerjaan pariwisata dapat beresiko terpapar wabah virus covid-19. UNWTO melaporkan bahwa selama enam bulan pertama ditahun 2020 perjalanan internasional guna tujuan wisata mengalami penurunan sebesar $65 \%$, penurunan ini adalah kasus pertama dalam sejarah pariwisata dunia dan mengakibatkan berkurangnya pendapatan eksport dari sektor pariwisata senilai USD460 milyar (WHO,2020). Badan PBB menyatakan membutuhkan waktu 2 - 4 tahun untuk dapat mengembalikan jumlah wisatawan mancanegara seperti kondisi sebelum pandemi.

Penurunan wisatawan paling tajam dalam periode enam bulan pertama selama 2020 adalah kawasan Asia dan Pasifik yakni sebesar 72\%, disusul Eropa sebesar $60 \%$. Ketidakpastian, himbauan resmi penutupan tempat-tempat wisata dan ketakutan menjadi penyebab turis maupun pelaku usaha wisata menghentikan kegiataan wisata. Hingga bulan Agustus Kerugian di sektor pariwisata sebesar 850 juta hingga 1,1 miliar wisatawan internasional, Kerugian pendapatan ekspor dari pariwisata sebesar US \$ 910 miliar hingga US \$ 1,2 triliun serta 100 hingga 120 juta pekerjaan berisiko (UNWTO,2020)

Hal yang sama terjadi terjadi pada kondisi pariwisata di Kabupaten Maluku Tenggara yang menutup dan menghentikan aktivitas wisata. Penutupan tempat wisata dilakukan sejak bulan April hingga bulan Juli 2020 dimana pemerintah sudah mengumumkan dimulainya masa kenormalam baru dan mulai dibukanya akses masuk dan keluar. Pelonggaran terhadap aktivitas industri pariwisata sejak diumumkannya masa new normal oleh pemerintah. Masa new normal adalah istilah yang digunakan untuk menggambarkan kondisi yang berbeda dengan kondisi sebelumnya yang kemudian akan menjadi suatu hal yang lumrah dan baru.

Buheji dan Ahmed (2020) mengemukakan bahwa kenormalan baru yakni kesiapan masyarakat untuk membangun kembali apa yang dibuat rubuh oleh suatu krisis maupun pandemik dengan kondisi yang lebih kuat kendati begitu dalam konteks pandemik, new normal juga diartikan sebagai perubahan yang terjadi pada perilaku manusia yang akan terjadi pada pasca pandemik covid-19, dimana manusia akan cenderung lebih membatasi sentuhan fisik dan juga 
akan cenderung lebih berjauhan dengan sesama (Griffith, 2020).

Istilah new normal adalah istilah yang digunakan terlebih dahulu dalam sektor ekonomi khususnya pada masa setelah krisis ekonomi dunia (Davis, 2009). Dua destinasi unggulan kabupaten Maluku Tenggara yakni Pantai Ngurbloat dan Pantai Ngursarnadan mulai membuka diri terhadap aktivitas wisata dengan memperhatikan protokol kesehatan. Hal ini menegaskan bahwa tatanan normal baru covid-19 mengharuskan masyarakat hidup berdampingan dengan virus covid 19, relaksasi ini dimaksudkan untuk menghidupkan kembali sektor pariwisata dan mendorong perekonomian. Tingginya wisatawan lokal yang berwisata pada Pantai Ngurbloat dan Pantai Ngursarnadan pada hari pertama pembukaan, menunjukan kebutuhan masyarakat terhadap aktivitas berwisata sangat tinggi. Perilaku wisatawan terhadap keputusan berwisata dalam masa new normal dapat dipicu oleh berbagai faktor. Wisatawan dalam hal ini adalah konsumen, tingkah lakunya dikaitkan dengan bagaimana suatu individu, kelompok dan organisasi memilih, membeli, menggunakan, dan bagaimana barang, jasa, jasa, ide, atau pengalaman untuk memuaskan kebutuhan dan keinginan mereka (Kotler dan Keller, 2008). Faktorfaktor yang mempengaruhi perilaku konsumen adalah kebudayaan, faktor sosial, pribadi, dan faktor psikologi. Kotler (1997) menegaskan faktor utama yang mempengaruhi perilaku konsumen dalam memilih yaitu faktor budaya, faktor sosial, faktor pribadi dan faktor psikologis. Menurut Sunarto (2004) pembelian konsumen secara kuat dipengaruhi oleh karakteristik budaya, sosial, pribadi dan psikologis. Faktor budaya merupakan kumpulan nilai-nilai dasar dan sekelompok orang yang mempunyai sistem nilai sama berdasarkan pada pengalaman hidup dan situasi (Yuriska dan Sukirno, 2014). Kebudayaan sangat mempengaruhi perilaku konsumen. Kebudayaan adalah penyebab paling dasar dan perilaku seseorang. Perilaku manusia sebagian besar dipelajari. Faktor sosial yaitu dua orang atau kelompok atau lebih yang berinteraksi untuk mencapai sasaran individu atau bersama hampir setiap masyarakat memiliki beberapa struktur kelas sosial (Yuriska dan Sukirno, 2014). Kelas sosial tidak ditentukan oleh faktor tunggal seperti pendapatan, tetapi diukur sebagai kombinasi dari pekerjaan, pendapatan, pendidikan, kekayaan, dan variabel lainnya (Malau, 2017). Faktor pribadi adalah sesuatu atau aspek yang melekat pada diri seorang individu yang mempengaruhi perilakunya (Yuriska dan Sukirno, 2014). Kepribadian merupakan suatu karakteristik individu mengenai kecenderungan merespon lintas situasi yang mirip (Supranto dan Limakrisna, 2011). Faktor psikologi adalah segala sesuatu aspek yang mampu mencitrakan/menggerakkan diri seorang individu berdasarkan ukuran motivasi, persepsi, pembelajaran maupun sikap pada setiap perilaku mereka (Yuriska dan Sukirno, 2014).

Proses pengambilan keputusan wisatawan dalam berwisata ke destinasi wisata Pantai Ngurbloat dan Ngursarnadan sangat penting diketahui oleh pemangku kepentingan atau pengelola kawasan wisata. Schiffman dan Kanuk (2007) menyatakan bahwa proses pengambilan keputusan sebagai proses penting dipengaruhi oleh lingkungan eksternal yang terdiri dari bauran pemasaran dan lingkungan sosial budaya dan lingkungan eksternal dalam hal ini faktor psikologi, sehingga menghasilkan proses pengambilan

ISSN: 2355-6587, e-ISSN: 2528-2220

http://ejournal.bsi.ac.id/ejurnal/index.php/jp 
keputusan dan keputusan akhir seseorang dalam berwisata ke tempat wisata. Titik awal untuk memahami perilaku konsumen adalah respon rangsangan. Tujuan penelitian ini adalah mengetahui dan menjelaskan pengaruh perilaku wisatawan baik secara simultan faktor-faktor pencentusnya ataukah secara parsial terhadap keputusan berwisata serta mana faktor yang paling menonjol mempengaruhi keputusan berwisata pada Pantai Ngurbloat dan Pantai Ngursardanan.

\section{KAJIAN LITERATUR Perilaku Konsumen}

Menurut Engel, Blackwell dan Miniard (1994) perilaku konsumen adalah tindakan yang langsung terlibat dalam mendapatkan, mengkonsumsi, dan menghabiskan produk dan jasa, termasuk proses yang mendahului dan menyusul dari tindakan tersebut.

Hal yang serupa telah lebih dulu diungkap oleh Mowen (1990) bahwa perilaku konsumen adalah studi unit - unit dan proses pembuatan keputusan yang terlibat dalam menerima, menggunakan dan penentuan barang, jasa, dan ide. Sedangkan menurut Setiadi (2008) perilaku konsumen adalah tindakan yang terlibat langsung dalam mendapatkan, mengkonsumsi, dan menghabiskan produk atau jasa, termasuk proses yang mendahului dan menyusuli tindakan ini. Kemudian Swastha dan Handoko (2000) mendefinisikan perilaku konsumen sebagai kegiatan - kegiatan individu yang secara langsung terlibat dalam mendapatkan dan mempergunakan barang - barang dan jasa - jasa, termasuk didalamnya proses pengambilan keputusan pada persiapan dan penentuan kegiatan - kegiatan tersebut. Pengertian perilaku konsumen lebih spesifik didefenisikan oleh Kottler (2009), bahwa perilaku konsumen adalah studi tentang bagaimana individu, kelompok, dan organisasi memilih, membeli, menggunakan, dan bagaimana barang, jasa, ide, atau pengalaman untuk memuaskan kebutuhan dan keinginan mereka. Menurut Kotler (1997) faktor utama yang mempengaruhi perilaku pembelian konsumen yaitu faktor budaya, faktor sosial, faktor pribadi dan faktor psikologis. Menurut Sunarto (2004) pembelian konsumen secara kuat dipengaruhi oleh karakteristik budaya, sosial, pribadi dan psikologis. Faktor budaya dipengaruhi oleh budaya, sub budaya dan kelas sosial. Budaya adalah penentu keingian dan perilaku yang paling mendasar. Budaya juga merupakan kumpulan nilai - nilai dasar, persepsi, keinginan dan tingkah laku yang dipelajari oleh seorang anggota masyarakat dari keluaraga dan lembaga penting lainnya. Menurut Schifman \& Kanuk (2008) budaya adalah keseluruhan kepercayaan, nilai - nilai, dan kebiasaan yang mempelajari yang membantu mengarahkan perilaku konsumen para anggota masyarakat tertentu. Faktor sosial Dalam faktor sosial, kelompok referensi, keluarga, peran sosial dan status mempengaruhi perilaku pembelian. Kelompok referensi (reference group) adalah semua kelompok yang mempunyai pengaruh langsung (tatap muka) atau tidak langsung terhadap sikap atau perilaku orang tersebut. Menurut Assel (dalam Sutisna, 2002) kelompok rujukan atau kelompok referensi adalah kelompok yang berfungsi sebagai poin rujukan bagi individu dalam membentuk kepercayaan, sikap dan perilakunya.

Faktor pribadi meliputi usia dan tahap dalam siklus hidup pembeli, pekerjaan dan keadaan ekonomi, kepribadian dan konsep diri, serta gaya hidup dan nilai. Seseorang mengubah barang dan jasa yang mereka beli selama hidup mereka. Selera terhadap makanan, pakaian, dan rekreasi sering kali berhubungan dengan usia. Pekerjaan seseorang akan mengarahkan pada kebutuhan dan keinginan seseorang dalam mengkonsumsi barang maupun jasa yang diinginkan. Pekerjaan juga mempengaruhi pola konsumsi. Pilihan produk sangat dipengaruhi oleh keadaan ekonomi yaitu pengahasilan yang dapat dibelanjakan, tabungan dan aset, kekuatan pinjaman, dan sikap terhadap pengeluaran dan tabungan. Menurut Stanton (1996) kepribadian 
adalah pola ciri - ciri seseorang yang menjadi determinan (faktor penentu) dalam perilaku responnya. Kepribadian adalah respon yang konsisten terhadap stimulus lingkungan (Engel, 1994). Sedangkan faktor psikologis dipengaruhi oleh faktor lingkungan yang terdiri dari keluarga, teman referensi, budaya dan status (Kartikasari, 2013).

\section{Keputusan Berkunjung}

Pengambilan keputusan konsumen menurut Peter-Olson yang dikutip oleh Nitisusastro (2013), adalah sebuah proses interaksi antara sikap afektif, kognitif dan behavioral terhadap faktor lingkungan. Sikap afektif sebagai keyakinan, sikap kognitif sebagai pemahaman, dan sikap behavioral sebagai sikap pada dunia yang nyata. Membeli atau tidak, merupakan bagian dari individu yang disebut behavior, dimana individu akan melihat pada dunia nyata. Ada tiga tahapan dalam proses pengambilan keputusan yakni masuknya informasi, pertimbangan konsumen untuk membeli, dan berakhir dengan pengambilan keputusan. Keputusan yang konsumen lakukan yang berkaitan dengan berwisata adalah keputusan wisatawan untuk mengunjungi objek wisata. Keputusan wisatawan untuk memilih objek wisata pada dasarnya merupakan salah satu bentuk pengambilan keputusan. Pada umumnya manusia bertindak rasional dalam mempertimbangkan jenis informasi yang tersedia dan mempertimbangkan segala resiko yang timbul dari tindakannya sebelum melakukan sebuah perilaku tertentu. Maka dari itu, sebelum memutuskan untuk melakukan pembelian, ada lima tahap yang dilalui konsumen dalam proses pembelian, yaitu pengenalan masalah, pencarian informasi, evaluasi alternatif, keputusan pembelian, dan Keputusan untuk memilih objek wisata pada dasarnya adalah keputusan "pembelian", yaitu mengeluarkan uang untuk mendapatkan kepuasan. Namun pembelian dalam konteks pariwisata mempunyai beberapa keleluasaan, (Pitana dan Gayatri, 2005).
Pitana dan Gayatri (2005) menyebutkan bahwa dalam keputusan melakukan perjalanan wisata terdapat 5 tahapan yakni : (1) kebutuhan atau keinginan untuk melakukan perjalanan, (2) pencarian dan penilaian informasi, (3) keputusan melakukan perjalanan wisata, (4) persiapan perjalanan dan pengalaman wisata, dan (5) evaluasi kepuasan perjalanan wisata. Berdasarkan teori diatas pada dasarnya proses dan tahapan pengambilan keputusan seorang wisatawan dimulai dari keinginan dan kebutuhan dari wisatawan untuk melakukan suatu perjalanan wisata. Setelah itu wisatawan mulai mengumpulkan informasi dari berbagai sumber mengenai objek wisata yang dituju dan kemudian mengevaluasi pilihan objek wisata yang menjadi pilihan paling tepat. Objek wisata yang dipilih tentunya yang sesuai dengan kebutuhan dan keinginan wisatawan tersebut. Setelah melakukan evaluasi maka selanjutnya wisatawan menetapkan objek wisata yang dikunjungi berdasarkan alternatif-alternatif pilihan yang telah diperoleh sebelumnya. Selanjutnya wisatawan melakukan persiapan untuk melakukan perjalanan dan melakukan kegiatan perjalanan tersebut perjalanan serta mendapatkan pengalaman selama melakukan perjalanan wisata. Setelah melakukan perjalanan wisata maka wisatawan mendapatkan kepuasan selama melakukan perjalanan wisatanya dan pada akhirnya mereka melakukan evaluasi terhadap perjalanan wisata yang telah dilakukan (Simamora, 2008)

\section{New Normal Covid-19}

Awal tahun 2020 hampir semua negara di dunia termasuk di Indonesia mengalami guncangan yang sangat berat. Guncangan itu disebabkan oleh virus corona. Penyakit ini disebabkan oleh virus korona jenis baru yang diberi nama SARS-CoV-2 Wabah COVID-19 pertama kali dideteksi di Kota Wuhan, Provinsi Hubei, Tiongkok pada bulan Desember 2019, dan ditetapkan sebagai pandemi oleh Organisasi Kesehatan Dunia (WHO) pada 11 Maret 2020. Pandemi COVID-19 adalah peristiwa menyebarnya penyakit korona virus 2019 di seluruh dunia.

ISSN: 2355-6587, e-ISSN: 2528-2220 
Hingga 23 April 2020, lebih dari 2.000.000 kasus covid-19 telah dilaporkan di lebih dari 210 negara dan wilayah, mengakibatkan lebih dari 195,755 orang meninggal dunia dan lebih dari 781,109 orang sembuh. Dampak virus ini bukan hanya dirasakan oleh Cina tetapi sudah menjangkau lebih dari 180 negara tersebar di semua benua, ditambah dengan dampak sosial, ekonomi, pendidikan dan dampak perubahan perilaku dan gaya hidup yang diakibatkan oleh mikroorganisme yang tak kasat mata ini.

New Normal adalah perubahan perilaku untuk tetap menjalankan aktivitas normal, tapi ditambah dengan penerapan protokol kesehatan guna mencegah terjadinya penularan Covid-19. Prinsip new normal adalah bisa menyesuaikan dengan pola hidup. Transformasi ini adalah untuk menata kehidupan dan perilaku baru, ketika pandemi, yang kemudian akan dibawa terus ke depannya sampai ditemukannya vaksin untuk Covid-19. Saputra (2020) menjelaskan, normal baru ini merupakan perilaku atau budaya baru yang muncul semenjak adanya virus corona. Beberapa perilaku yang ketika sebelum pandemi menjadi hal yang tak lazim maka kini berangsur jadi hal yang biasa menjadi normal yang baru. Sedangkan jika menurut Ahli Epidemiologi dari Griffith University Australia, Budiman (2020), new normal tak hanya soal kebiasaan baru individu. New normal terbagi menjadi dua tingkatan yakni untuk individu atau komunitas dan new normal di tataran institusi. The new normal ini ada dua level, level pada komunitas dan individu, ada juga untuk institusi.

WHO dan berbagai negara mulai mendeklarasikan tatanan baru untuk hidup berdampingan dengan covid-19, dengan gagasan "new Normal". Kebutuhan normalisasi kehidupan melalui pemfungsian kembali aktivitas social dan ekonomi akibat kekhawatiran akan resesi ekonomi. New normal adalah mekanisme transisi untuk mendorong kembalinya bergulir aktivitas ekonomi dan sosial. New normal muncul sebagai respon atas covid19. Secara umum istilah ini merujuk pada hadirnya tatanan baru sebagai bentuk respon atas situasi krisis. New normal merupakan bentuk perubahan yang dipicu oleh krisis dan adaptasi sistem baru yang bias mencegah terjadinya kembali atau mempersiapkan diri menghadapi situasi krisis. Tatanan baru masyarakat yang terbentuk sebagai akibat situasi krisis dan kelembagaan sisitem manajemen kembencanaan yang lebih komprehensif adalah gambaran dari new normal (Mas'udi dan Winanti, 2020)

Ketidakpastian berakhirnya pandemi COVID-19, mengharuskan kita untuk mampu beradaptasi dengan kondisi baru, prasyarat baru (social and physical distancing), tatanan baru (fisik, sosial dan kesehatan), dengan mempersiapkan protokol new normal order. Pemulihan aktivitas sektor wisata harus mewaspadai munculnya klaster baru pada destinasi wisata, yang disebabkan terabaikannya protokol kesehatan (Paramitha dan Putra, 2020). Menurut hasil penelitian dari Paramitha dan Putra (2020), ada beberapa hal yang dapat dilakukan oleh pelaku pariwisata untuk memberikan rasa aman dan nyaman berwisata di masa pandemi ini yakni: 1. High Standard Sanitation. Penerapan standar kesehatan dengan membuat sanitasi yang memadai dengan menyiapkan destinasi sesuai dengan kondisi 'new normal' dengan mengedepankan prinsip sustainable tourism, termasuk di dalamnya soal kesehatan, dan keamanan (Wahyudi, 2020). 2. High Standard Security yakni standar keamanan adalah hal penting yang wajib diperhatikan. 3. Staycation. Beberapa hal yang akan kita temui pada 'new normal' setelah Covid-19 dalam bidang pariwisata adalah wisatawan yang akan mengutamakan kesehatan dan keselamatan seperti tetap melaksanakan self-distancing, pelaksanaan protokol Covid-19, sehingga ketersediaan sarana kebersihan akan menjadi fokus utama para pelaku pariwisata. 4. Niche tourism. Perubahan yang sangat besar akan terlihat dari kelompok wisatawan dalam berwisata. Jika dahulu mereka berada dalam kelompok yang besar karena akan menghemat anggaran. Tetapi mengingat

ISSN: 2355-6587, e-ISSN: 2528-2220

http://ejournal.bsi.ac.id/ejurnal/index.php/jp 
standar yang tinggi akan keamanan dan kenyamanan maka pilihan Niche tourism menjadi sangat penting karena mereka akan ada dalam kelompok kecil dengan kesamaan hobi, ketertarikan atau kesamaan visi. 5. Solo travel tour. Penggunaan individual transportation akan lebih tinggi dibandingkan mass transport karena physical distancing ini akan berlangsung lebih lama dari perkiraan kita sebelumnya sehingga ketakutan wisatawan untuk berada dalam satu moda transportasi dapat dihindari. Alternatif lain yang bisa dilakukan oleh para pelaku wisata adalah memberikan pelayanan terbaik bagi para turis dengan mengatur tempat duduk pada transportasi umum.

\section{METODE PENELITIAN}

\section{Lokasi Penelitian}

Penelitian ini dilakukan pada dua destinasi unggulan Kabupaten Maluku Tenggara yang terletak pada pada latitude $5,664102^{0}$ dan longitude $136,635177^{\circ}$ sampai dengan latitude $-5644318^{\circ}$ dan longitude 136,3637302 ${ }^{\circ}$. Pantai Ngurbloat dan Ngursardanan terletak pada Ohoi (Desa) Ngilngof dan Ohoi (Desa) Ohoililir. Ngilngof dan Ohoililir adalah dua desa bersebelahan dengan karakteristik adat, budaya, serta kondisi alam yang serupa. Karakteristik pasir putih halus, panorama sun set dan air biru jernih menjadi ciri khas kedua destinasi tersebut. Pasir putih halus membentang dan menghubungkan Pantai Ngurbloat dan Pantai Ngursarnadan.

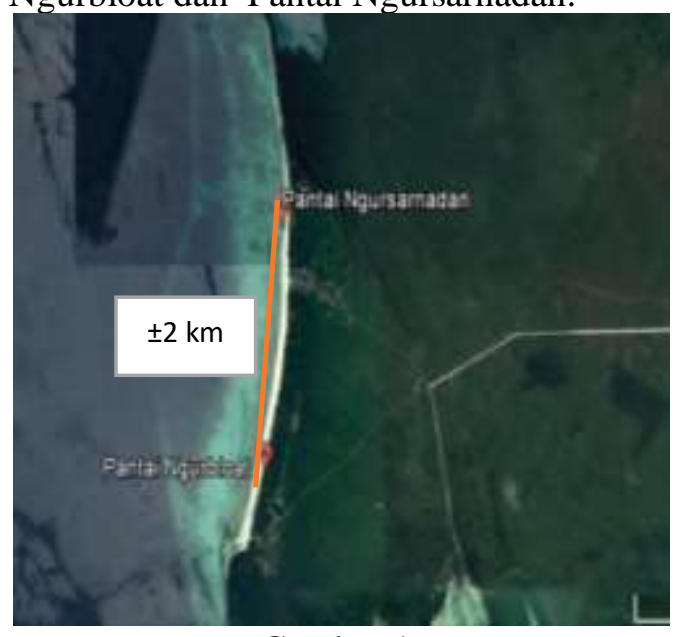

Gambar 1.

Peta Lokasi Penelitian

Sumber : Dokumentasi Penelitian (2020) mengisi ulang tubuh dan menyehatkan pikiran. Wellness tour ini menawarkan keseimbangan sempurna antara tujuan dan juga mengutamakan moda transportasi sabun cuci tangan, tissue di setiap mobil dalam mobil, menyediakan hand sanitizer, pribadi untuk kelompok kecil. 6. Wellness tour. Wisata yang satu ini diciptakan untuk yang menakjubkan, kegiatan peremajaan, dan pengalaman makanan sehat sehingga akan membantu wisatawan yang kembali ke rumah dengan perasaan lebih baik daripada ketika mereka sebelum bepergian pergi. 7. Virtual tourism. Teknologi yang berkembang dalam bidang pariwisata yaitu meningkatnya platform atau aplikasi yang mampu memberikan pengalaman nyata berwisata ke objek-objek wisata.

\section{Karangka Penelitian}

Model penelitian akan dapat menggambarkan hubungan yang terjadi antara variabel, baik variabel yang terikat maupun variabel yang tidak terikat. Model penelitian ini dapat juga disebut sebagai kerangka konseptual penelitian. Hal sesuai dengan pendapat dari Sugiyono (2011) yang memberikan pengertian kerangka konseptual atau kerangka berfikir yaitu merupakan sintesa tentang hubungan antara variable yang disusun dari berbagai teori yang telah di deskripsikan. Model penelitian ini dapat dilihat seperti yang tampak pada gambar berikut ini:

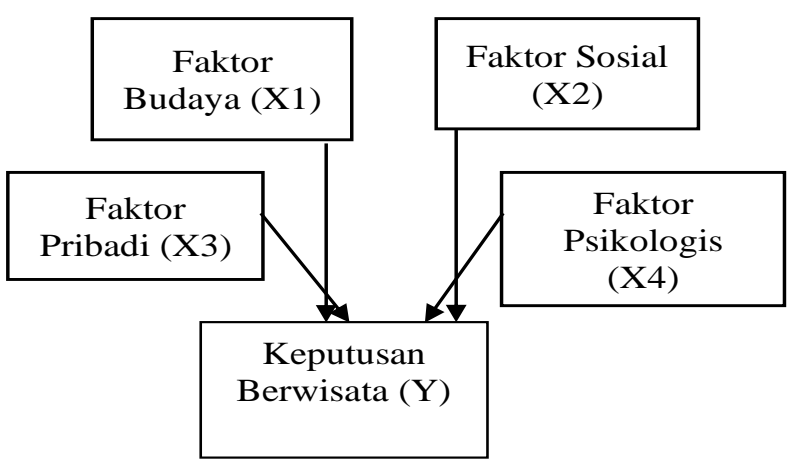

Gambar 2.

Karangka Penelitian

Sumber : Data Penelitian (2020)

Variabel bebas terdiri dari faktor budaya (X1), faktor sosial (X2), faktor pribadi (X3) dan faktor psikologis (X4). Dengan hipotesa penelitian sebagai berikut: (A) Variabel Budaya ( X1), Sosial (X2),

ISSN: 2355-6587, e-ISSN: 2528-2220

http://ejournal.bsi.ac.id/ejurnal/index.php/jp 
Pribadi (X3), dan Psikologis (X4) secara bersama - sama berpengaruh terhadap Keputusan wisatawan berkunjung (Y); (B) Variabel Budaya (X1), Sosial (X2), Pribadi (X3), dan Psikologis (X4) secara parsial berpengaruh terhadap Keputusan wisatawan berkunjung (Y); (C) Salah satu variabel mempunyai pengaruh dominan terhadap Keputusan wisatawan berkunjung.

\section{Metode Pengaambilan Data}

Metode pengumpulan data pada penelitian ini menggunakan kuesioner dan wawancara. Dalam menentukan pengambilan sampel, digunakan non probability sampling (tidak acak) khususnya menggunakan purposive sampling. Menurut Sugiyono (2007) purposive sampling adalah teknik penentuan sampel dengan pertimbangan tertentu. Responden dalam penelitian ini adalah wisatawan yang berkunjung pada

Tabel 1.

Validitas Kuesioner

\begin{tabular}{|c|c|c|c|}
\hline $\begin{array}{r}\text { Variabel X1 } \\
\text { Faktor Budaya }\end{array}$ & \multicolumn{2}{|c|}{ Faktor Budaya } & Hasil Validitas \\
\hline $\mathrm{X} 1.1$ & 0.571 & & Valid \\
\hline $\mathrm{X} 1.2$ & 0.720 & & Valid \\
\hline $\mathrm{X} 1.3$ & 0.800 & & Valid \\
\hline $\mathrm{X} 1.4$ & 0.697 & & Valid \\
\hline $\mathrm{X} 1.5$ & 0.576 & & Valid \\
\hline \multicolumn{4}{|l|}{ Variabel X2 } \\
\hline \multicolumn{4}{|l|}{ Faktor Sosial } \\
\hline $\mathrm{X} 2.1$ & 0.449 & & Valid \\
\hline $\mathrm{X} 2.2$ & 0.445 & & Valid \\
\hline $\mathrm{X} 2.3$ & 0.561 & & Valid \\
\hline X2.4 & 0.420 & & Valid \\
\hline $\mathrm{X} 2.5$ & 0.580 & & Valid \\
\hline \multicolumn{4}{|l|}{ Variabel X3 } \\
\hline \multicolumn{4}{|l|}{ Faktor Pribadi } \\
\hline $\mathrm{X} 3.2$ & 0.814 & & Valid \\
\hline X3.2 & 0.644 & & Valid \\
\hline X3.3 & 0.754 & 0.1317 & Valid \\
\hline X 3.4 & 0.764 & & Valid \\
\hline X3.5 & 0.470 & & Valid \\
\hline \multicolumn{4}{|l|}{ Variabel X4 } \\
\hline \multicolumn{4}{|c|}{ Faktor Psikologis } \\
\hline $\mathrm{X} 4.1$ & 0.665 & & Valid \\
\hline $\mathrm{X} 4.2$ & 0.680 & & Valid \\
\hline $\mathrm{X} 4.3$ & 0.677 & & Valid \\
\hline $\mathrm{X} 4.4$ & 0.627 & & Valid \\
\hline $\mathrm{X} 4.5$ & 0.683 & & Valid \\
\hline \multicolumn{4}{|l|}{ Variabel Y } \\
\hline Keputusan berwisa & & & \\
\hline Y1.1 & 0.644 & & Valid \\
\hline $\mathrm{Y} 1.2$ & 0.756 & & Valid \\
\hline Y1.3 & 0.744 & & Valid \\
\hline Y1.4 & 0.832 & & Valid \\
\hline Y1.5 & 0.707 & & Valid \\
\hline
\end{tabular}

dua lokasi penelitian. Banyaknya sampel dalam penelitian ini dihitung menggunakan rumus slovin dengan taraf signifikan sebesar 5\% adalah sebanyak 222. Pengambilan data dilakukan pada akhir pekan yakni sabtu dan minggu dalam bulan September - Oktober 2020

\section{Metode Analisa Data}

Dalam penelitian ini analisis yang digunakan adalah analisis regresi linear berganda

\section{Validitas dan Reliabilitas Kuesioner}

Agar data yang diperoleh mempunyai tingkat akurasi dan konsistensi tinggi, maka instrumen penelitian yang akan digunakan harus valid dan reliabel. Dikatakan suatu kuesioner valid jika nilai r-hitung lebih besar dari nilai r-tabel.

Sumber : Data primer yang diolah (2020)

ISSN: 2355-6587, e-ISSN: 2528-2220

http://ejournal.bsi.ac.id/ejurnal/index.php/jp 
Perbandingan nilai $r$ hitung dan $r$ tabel dapat dilihat pada tabel 1 . Berdasarkan tabel 1, maka dengan membandingkan nilai r-hitung dan r-tabel dapat disimpulkan bahwa semua item kuesioner memiliki nilai $r$ hitung lebih besar dari r-tabel sehingga kuesioner dalam penelitian dikatakan valid.

Suatu kuesioner dikatakan reliabel atau handal jika jawaban seseorang terhadap pernyataan adalah konsisten dari waktu ke waktu. Kesimpulan apakah kuesioner penelitian reliable atau tidak ber dasarkan pada kriteria Nunnally (1967), apabila nilai Cronbanch alpha lebih besar dari 0,6 atau 60 persen maka dianggap reliable. Nilai koefisien Cronbach's Alpha untuk variabel faktor budaya, faktor sosial, faktor pribadi, dan faktor psikologi dan keputusan berwisata memiliki nilai lebih dari 0,6 atau lebih daru $60 \%$, dengan demikian dapat disimpulkan bahwa kuesioner yang digunakan oleh masingmasing variabel penelitian terbukti handal atau reliable (tabel 2).

Tabel 2.

Reliabelitas Data

\begin{tabular}{ccc}
\hline Item & Cronbach's Alpha & Reliabilitas \\
\hline Faktor Budaya (X1) & 0.705 & Reliabel \\
Faktor Sosial (X2) & 0.733 & Reliabel \\
Faktor Pribadi (X3) & 0.732 & Reliabel \\
Faktor Psikologis (X4) & 0.682 & Reliabel \\
Keputusan berwisata (Y) & 0.790 & Reliabel \\
\hline
\end{tabular}

Sumber : Data primer yang diolah (2020)

\section{PEMBAHASAN}

Hasil analisa regresi linier berganda pada penelitian ini dimaksudkan untuk mengetahui apakah ada pengaruh antara tiap - tiap faktor pencetus terhadap keputusan berwisata dan apakah secara simultan faktor pencetus berpengaruh terhadap keputusan berkunjung wisatawan pada kondisi new normal setelah pandemi covid 19. Hasil penelitian ini kemudian menunjukan bahwa faktor budaya, faktor sosial, faktor pribadi dan faktor psikologis secara bersama-sama mempengaruhi keputusan wisatawan berkunjung ke Pantai Ngurbloat dan Ngursarnadan. Dimana nilai probabilitas (sig) sebesar 0.000 atau lebih kecil dari alfa 0.05 (tabel 6).

\begin{tabular}{|c|c|c|c|c|c|c|}
\hline \multicolumn{7}{|c|}{$\begin{array}{r}\text { Taber o. } \\
\text { Anova }\end{array}$} \\
\hline \multicolumn{2}{|c|}{ Model } & \multirow{2}{*}{$\begin{array}{c}\begin{array}{c}\text { Sum of } \\
\text { Square } \\
\text { s }\end{array} \\
721.55\end{array}$} & \multirow{2}{*}{$\begin{array}{r}\text { df } \\
4\end{array}$} & \multirow{2}{*}{$\begin{array}{c}\begin{array}{c}\text { Mean } \\
\text { Square }\end{array} \\
180.389\end{array}$} & \multirow{2}{*}{$\begin{array}{c}\mathbf{F} \\
38.746\end{array}$} & \multirow{2}{*}{$\begin{array}{l}\text { Sig. } \\
.000\end{array}$} \\
\hline 1 & $\begin{array}{l}\text { Regre } \\
\text { ssion }\end{array}$ & & & & & \\
\hline & $\begin{array}{l}\text { Resid } \\
\text { ual }\end{array}$ & $\begin{array}{r}442.28 \\
4\end{array}$ & $\begin{array}{l}9 \\
5\end{array}$ & 4.656 & & \\
\hline & Total & $\begin{array}{r}1163.8 \\
40\end{array}$ & $\begin{array}{l}9 \\
9\end{array}$ & & & \\
\hline \multicolumn{7}{|c|}{ a. Dependent Variable: Y } \\
\hline \multicolumn{7}{|c|}{$\begin{array}{l}\text { b. Predictors: (Constant), F.Psikologis, F.Sosial, F.Budaya, } \\
\text { F.Pribadi }\end{array}$} \\
\hline
\end{tabular}

ISSN: 2355-6587, e-ISSN: 2528-2220

http://ejournal.bsi.ac.id/ejurnal/index.php/jp 
dan mengarahkan perilaku konsumen para anggota masyarakat tertentu (Schifman \& Kanuk, 2008). Pada penelitian ini terlihat bahwa kegiatan berwisata pada masa new normal adalah kebutuhan hidup semua orang tidak terikat pada budaya dan kelas sosial. Menurut Schifman dan Kanuk (2008), dampak budaya dalam masyarakat demikian alami dan berurat berakar sehingga pengaruhnya kepada perilaku jarang diperhatikan. Maka dalam penelitian ini dapat disimpulkan bahwa faktor budaya bukanlah sesuatu yang dominan mempengaruhi keputusan wisatawan untuk berkunjung ke destinasi wisata Pantai Ngurbloat dan Pantai Ngursarnadan.

Pada Penelitian ini faktor pencetus lainya adalah faktor sosial. Faktor sosial berpengaruh signifikan dan positif terhadap keputusan berwisata ditengah situasi pandemi covid-19 yang belum berakhir. Dimana signifikan faktor sosial lebih kecil dari 0.05 atau $0.004<0.05$. Hal yang sama juga terlihat pada faktor pribadi yang mana berpengaruh signifikan dan positif terhadap keputusan berwisata dengan nilai probabilitas (Sig) dari factor pribadi sebesar 0.003 atau lebih kecil dari $0.05(0.003<0.05)$. Hasil analisa data juga menunjukan bahwa faktor pencetus psikologis juga berpengaruh signifikan dan positif terhadap variabel $Y$. Nilai probabilitas (Sig) dari factor psikologis sebesar 0.000 atau lebih kecil dari 0.05 $(0.000<0.05)$ sehingga dapat disimpulkan bahwa faktor sosial, faktor pribadi dan faktor psikologis mempengaruhi keputusan berwisata di era tatanan baru covid-19 secara parsial pada destinasi wisata pantai Ngurbloat dan Ngursarnadan.

Pada faktor sosial, pengaruh dari kelompok referensi, keluarga, peran sosial dan status mempengaruhi perilaku pembelian jasa dimana pariwisata merupakan industri jasa terbesar. Kelompok referensi (reference group) adalah semua kelompok yang mempunyai pengaruh langsung (tatap muka) atau tidak langsung terhadap sikap atau perilaku orang tersebut. Menurut Assel dalam Sutisna (2002) kelompok rujukan atau kelompok referensi adalah kelompok yang berfungsi sebagai poin rujukan bagi individu dalam membentuk kepercayaan, sikap dan perilakunya. Pada penelitian ini kelompok referensi adalah keluarga dan teman yang mana berpengaruh langsung terhadap perilaku wisatawan dalam membuat keputusan berwisata pada pantai Ngurbloat dan Ngursarnadan. Dalam situasi tatanan baru covid -19 kebutuhan akan berwisata atau berekreasi sama pentingnya dengan kepercayaan terhadap fasilitas pendukung protocol kesehatan yang ada pada objek wisata. Sehingga saran atau rujukan tempat wisata yang menyediakan fasilitas sesuai standar protocol kesehatan bagi wisatawan dari teman dan atau keluarga, kuat dampaknya dalam mempengaruhi keputusan wisatawan untuk berkunjung. Berdasarkan hasil penelitian, faktor pribadi adalah faktor kedua yang paling dominanan dengan nilai koefisien regresi sebesar 0.260 dan berpengaruh positif yang berarti jika variable faktor pribadi mengalami kenaikan satu satuan maka keputusan berwisata akan mengalami peningkatan sebesar 0.260. Faktor pribadi meliputi usia dan tahap dalam siklus hidup pembeli, pekerjaan dan keadaan ekonomi, kepribadian dan konsep diri, serta gaya hidup dan nilai. Seseorang mengubah barang dan jasa yang mereka beli selama hidup mereka. Gaya hidup sehat dan bersih di era tatanan baru covid-19 menjadi alasan kuat keputusan wisatawan berwisata pada pantai Ngurbloat dan Ngursarnadan yang memiliki kawasan wisata yang luas sehingga mendukung social distancing serta penerapan protocol kesehatan yang baik pada kedua destinasi wisata tersebut. Gaya hidup sehat dan bersih diberlakukan pada kedua destinasi wisata Ngurbloat dan Ngursarnadan memberikan rasa nyaman dan aman kepada pengunjung dan mempengaruhi keputusan berwisata. Selain itu selera terhadap makanan, pakaian, dan rekreasi sering kali berhubungan dengan usia. Dalam penelitian ini keputusan berwisata ke pantai Ngurbloat dan Ngursarnadan dilakukan karena kedua destinasi tersebut dapat dinikmati oleh semua usia selain itu harga tiket masuk dan harga makanan dan minuman yang murah

ISSN: 2355-6587, e-ISSN: 2528-2220

http://ejournal.bsi.ac.id/ejurnal/index.php/jp 
di masa pandemi covid-19 sesuai dengan kondisi ekonomi wisatawan.

$\begin{array}{cc} & \text { Faktor psikologis merupakan faktor } \\ \text { yang } & \text { paling dominan dalam }\end{array}$ mempengaruhi keputusan berwisata wisatawan. Pada tabel 7 terlihat koefisien sebesar 0.497 dan bernilai positif. Bernilai positif berarti jika faktor psikologi mengalami kenaikan sebesar satu satuan maka keputusan berwisata akan mengalami kenaikan sebesar 0.497. Hal yang sama juga dikemukakan dalam penelitian Marliani dan Sugiarto (2019), yang mennyatakan bahwa variable faktor psikologis menunjukkan angka yang lebih besar dan paling berpengaruh signifikan secara statistic dari variabel lainnya sehingga dapat dikatakan bahwa variabel faktor psikologis merupakan variabel yang paling dominan secara sta tistik berpengaruh terhadap pengambilan keputusan konsumen dalam melakukan kunjungan wisata di Kabupaten Hulu Sungai Tengah.

Faktor psikologis terdiri dari motivasi, persepsi, pembelajaran, keyakinan dan sikap. Dalam penelitian ini motivasi wisatawan untuk berwisata pada kedua destinasi karena aspek kesehatan. Kondisi ketidakpastian akibat pandemi mengharuskan para wisatawan maupun pengelola destinasi wajib menjalankan protokol kesehatan. Destinasi wisata pantai Ngurbloat dan pantai Ngursarnadan adalah pelopor bagi objek wisata lainnya. Sehingga mempengaruhi motivasi dan sikap wisatawan untuk berwisata. Dapat disimpulkan bahwa faktor sosial, faktor pribadi dan faktor psikologis secara parsial mempengaruhi keputusan berwisata.

\begin{tabular}{|c|c|c|c|c|c|c|c|c|}
\hline \multicolumn{9}{|c|}{$\mathrm{Tab}$} \\
\hline \multicolumn{2}{|c|}{ Model } & \multicolumn{2}{|c|}{$\begin{array}{l}\text { Unstandardize } \\
\text { d Coefficients }\end{array}$} & \multirow{2}{*}{$\begin{array}{l}\text { Standa } \\
\text { rdized } \\
\text { Coeffi } \\
\text { cients } \\
\text { Beta }\end{array}$} & \multirow[t]{2}{*}{$\mathrm{t}$} & \multirow[t]{2}{*}{ Sig. } & \multicolumn{2}{|c|}{$\begin{array}{l}\text { Collinearity } \\
\text { Statistics }\end{array}$} \\
\hline & & B & $\begin{array}{l}\text { Std. } \\
\text { Error }\end{array}$ & & & & Tolerance & VIF \\
\hline \multirow[t]{5}{*}{1} & (Constant) & 2.325 & 1.431 & & 1.624 & .108 & & \\
\hline & F.Budaya & .013 & .075 & .013 & .177 & .860 & .742 & 1.348 \\
\hline & F.Sosial & .181 & .062 & .212 & 2.923 & .004 & .758 & 1.318 \\
\hline & F.Pribadi & .268 & .087 & .260 & 3.075 & .003 & .560 & 1.786 \\
\hline & $\begin{array}{l}\text { F.Psikolo } \\
\text { gis }\end{array}$ & .487 & .078 & .497 & 6.285 & .000 & .640 & 1.563 \\
\hline
\end{tabular}

a. Dependent Variable: Y

Sumber : Data primer yang diolah (2020)

\section{PENUTUP}

Dari penelitian dapat disimpulkan bahwa faktor budaya, faktor sosial, faktor pribadi dan faktor psikologis secara bersama-sama mempengaruhi keputusan wisatawan untuk berkunjung. Sedangkan Faktor sosial, pribadi dan psikologis secara parsial mempengaruhi keputusan wisatawan untuk berkunjung ke pantai Ngurbloat dan Ngursarnadan. Penelitian ini dilaksanakan pada masa awal new normal, sehingga kedua destinasi wisata tersebut belum ramai dikunjungi sehingga perlu adanya penelitian serupa dimasa akan datang untuk menggambarkan perilaku wisatawan berkunjung ke Pantai Ngurbloat dan Ngursarnadan dimasa setelah new normal.

\section{REFERENSI}

Budiman, D. 2020. Penerapan New Normal di Indonesia, Epidemiolog: Jangan Buru-Buru. https://nasional.okezone.com/read/2 020/05/27/337/2220455/penerapannew-normal-di-indonesiaepidemiolog-jangan-buru-buru. Diakses pada tanggal 5 September 2020

Buheji, M., Ahmed, D. 2020. Planning Competency in the New NormalEmployability Competency in PostCovid-19 Pandemic. Business Management and Strategy, 160-179

Davis, I. 2009. The New Normal. The Mckinsley Quarterly. Mckinaley and Company 
Kartikasari, Didin. 2013. Pengaruh Perilaku Konsumen Terhadap Keputusan Pembelian (Penelitian pada Mahasiswa Administrasi Bisnis Angkatan 2012/2013 Fakultas Ilmu Administrasi Universitas Brawijaya yang Mengkonsumsi Produk Mie Instan merek Indomie). Jurnal: Administrasi Bisnis. Vol 3 No 2 (2013). Universitas Brawijaya. http://administrasibisnis.studentjour nal.ub.ac.id

Engel, James F., Roger D Blackwell, \& Paul W Miniard. 1994. Perilaku Konsumen, Alih bahasa Budiyanto, Jakarta : Binarupa Aksara

Griffith, K. 2020. The new normal after corona virus.

Kotler, P., \& Keller, K.L. (2007). Manajemen Pemasaran (Edisi 13). Jakarta: Erlangga.

Malau, H. 2017. Manajemen Pemasaran Teori dan Aplikasi Pemasaran Era Tradisional Sampai Era Modernisasi Global. Bandung: Alfabeta

Marliani, G.,Sugiarto, T. 2019. Pengaruh Perilaku Konsumen terhadap Pengambilan Keputusan dalam Menentukan Destinasi Wisata di Kabupaten Hulu Sungai Tengah. Jurnal Riset Inspirasi Manajemen dan Kewirausahaan Vol 23, 2(8084). e-ISSN: 2623-1077

Mas'udi, Wawan \& Winanti, S. P. 2020. New Normal: Perubahan social ekonomi dan politik akibat covid19. Gajah Mada University Press

Mowen, Jonh C \& Michael Minor. 2002. Prilaku Konsumen Edisi Kelima Jilid 1. Alih Bahasa : Lina Salim. Jakarta : Erlangga. Noviyanto, $\mathrm{H}$

Nunnally, J. 1967. Psycometric Method. New York: McGraw-Hill

Pitana, I Gede \& Gayatri, Putu G.(2005). Sosiologi Pariwisata, Yogyakarta: CV Andi Offset.

Schiffman, Leon \& Kanuk, L. Lazar. 2008. Perilaku Konsumen. Alih Bahasa : Zoelkifli Kasip. Jakarta : PT. INDEKS.
Simamora, Bilson. (2008). Panduan Riset Perilaku Konsumen, Jakarta: PT Gramedia Pustaka Utama.

Stanton, William. (1996). Prinsip-prinsip Pemasaran, Jilid Kedua, Edisi Ketujuh, Erlangga : Jakarta.

Sugiyono. 2007. Statistika Untuk Penelitian, Cetakan kedua belas. Bandung: Alfabeta

Sutisna. 2002. Perilaku konsumen \& komunikasi pemasaran. Bansung. Pt remaja rosdakarya

Supranto, J., \& Limakrisna, N. 2011. Perilaku Konsumen \& Strategi Pemasaran Untuk Memenangkan Persaingan Bisnis, edisi kedua. Jakarta: Mitra Wacana Media.

Swastha DH, Basu \& Handoko. 2000. Manajemen Pemasaran, Analisa Perilaku Konsumen. Yokyakarta : BPFE.

Yuriska, M.R., \& Sukirno, I. (2014) Pengaruh Faktor Sosial, Personal, Psychological dan Kultural Terhadap Keputusan Pembelian Konsumen Centro Department Store Melalui Stimulus Midnight Sale. Modus, 26 (1), 77-84. ISSN: 08521875

Wahyudi, E. 2020. Perubahan tren pasca covid-19 diprediksi positif bagi pariwisata. Tempo.Co. Diunduh dari https://bisnis.tempo.co/read/133560 3/perubahan-trenpasca-covid-19diprediksi-positif-bagipariwisata/full\&view $=$ ok. Diakses pada tanggal 20 juli 2020

World Tourism Organization. 2020. International Tourism and COVID19. https://www.unwto.org/unwtotourism-dashboard. Diakses pada tanggal 23 September 2020

\section{BIODATA PENULIS}

Ida I Dewa Ayu Raka Susanty, ,MM adalah dosen tetap program studi DIV Agrowisata Bahari politeknik perikanan negeri tual. Fokus manajemen pariwisata.

Melissa Justine Renjaan, S.Kel.,M.Si, adalah salah satu dosen tetap pada program studi DIV Agrowisata Bahari politeknik perikanan negeri tual. Fokus membidangi lingkungan

ISSN: 2355-6587, e-ISSN: 2528-2220 